NALI2020_81

\title{
INITIATING A PROFESSIONAL DEVELOPMENT ON ACTION RESEARCH DURING THE COVID-19 PANDEMIC
}

\author{
Mohd Syafiq Aiman Mat Noor**1, Satirah Ahmad ${ }^{2}$ and Zailah Zainudin ${ }^{3}$ \\ ${ }^{1}$ University College London, UNITED KINGDOM. \\ (E-mail: m.noor.14@ucl.ac.uk) \\ ${ }^{2}$ Institute of Teacher Education, International Languages Campus, Kuala Lumpur, MALAYSIA. \\ (E-mail: satirahahmad@ipgm.edu.my) \\ ${ }^{3}$ Institute of Teacher Education, Raja Melewar Campus, Seremban, MALAYSIA. \\ (E-mail: dr.zailah@ipgm.edu.my) \\ *corresponding author
}

\begin{abstract}
In the uncertain environment of the COVID-19 pandemic, it is important that professional development for Malaysian educators continues, even if it cannot happen in person. In response, we developed this study to deliver online Continuous Professional Development (CPD) on action research among Malaysian educators. The paper seeks to answer two main questions: i) How do we promote and conduct online CPD on action research during the movement control order (MCO)?, and ii) How do educators exhibit their professional development as a result of participating in the online CPD? The study utilised action research as a model of CPD to impart understandings about action research processes to the educators. In the initial stages, we used social media platforms and mobile applications to promote and create awareness of the online CPD. As a result, educators $(n=215)$ from different levels of education registered and participated in the online CPD on action research. We then conducted a series of online CPD programmes on action research using video conferencing tools. Our effort to provide online CPD on action research has: i) helped educators to develop new knowledge directly related to their teaching practices, ii) promoted reflective teaching and thinking, and iii) expanded educators' pedagogical repertoire. The study also indicated that the participating educators exhibited their professional development and deepened their knowledge related to the four areas: pedagogical knowledge, pedagogical content knowledge, content knowledge, and knowledge of learners and learning. It is therefore suggested that action research as a model of CPD should be nurtured among educators in Malaysia.
\end{abstract}

\section{Keywords: Professional Development, Action Research, COVID-19 Pandemic}

\section{INTRODUCTION}

The Coronavirus (COVID-19) outbreak is causing various levels of disruption in education globally. Malaysia announced school and other education institution closures on 18 March 2020, with less than 26 hours' notice, in an attempt to slow the spread of the disease (see PMO, 2020). This has impacted just below five million students in the country (MOE, 2019). The purpose of these school and other education institution closures is to prevent further transmission of COVID-19 through self-isolation, shielding and social distancing during the movement control order (MCO) (MOE, 2020). 
Despite the fact that schools and other education institutions are disrupted by the COVID-19 pandemic, unlike any time in the past, we have the ability to ensure that education can continue, even when schools and other education institutions are closed. Thus, during the implementation of the MCO, the Ministry of Education, Malaysia (MOE) and Ministry of Higher Education, Malaysia (MOHE) are committed to ensuring that students are not left behind and are able to continue their learning in a safe manner. They are doing so by urging all educators to carry out distance teaching and learning. Assuming Malaysian parents, students and educators are ready for distance teaching and learning, the question remains: how should it be delivered?

In an attempt to address this issue, we have come up with an initiative to provide online Continuous Professional Development (CPD) to educators all over Malaysia in order to help them see the relevance of action research in dealing with the challenges of distance teaching and learning during the COVID-19 pandemic. The study employs action research, which offers a systematic and intentional approach for educators to carry out research on their own professional and pedagogical practices. Action research aims to change practices, people's understandings of their practices, and the conditions under which they practice (Kemmis, et al., 2014). The transformation of practices involves transformations in how people e.g. educators, understand their practices, what they do, and how they relate to one another in practice. Our ways of saying, doing and relating can each be transformed, but always in relation to other people. We argue that the educators involved in the action research processes will be able to articulate their area of professional practice for development. For example, educators could choose to transform a particular kind of educational practice (doing) - like the shift from face to face teaching and learning to distance teaching and learning. They might also embark on a paradigm shift from a conservative view of education as transmission of knowledge, skills and values to a liberal view of education as self-formation (shifts in ways of thinking, saying and relating, as well as in ways of doing).

This study was the sum of our efforts to help educators in their professional development. The aim was to enable them to reflect on their own practice and hence improve the way they conduct distance teaching and learning throughout the COVID-19 pandemic. It is important to note that the study's aim is not to provide online CPD for educators to design curriculum instruction on distance teaching and learning for their students and to manage its technological component. Rather, we invited educators to be involved in the action research process and to carry out research into their own professional and pedagogical practices. The term action research was introduced by Kurt Lewin (1948), who described it as a cyclical process of four iterative research stages: reflecting, planning, acting, and observing. Action research for the purpose of achieving social change has a longstanding association with development (see Fals-Borda, 1987). There have also been recent significant shifts and innovations in practice, which have emphasised action research is fundamentally concerned with changes in practice, in the context of schools, workplaces, hospitals and other organisational contexts (Townsend, 2014). 
We attest that action research will enable educators to critically evaluate their own professional and pedagogical practices in these unprecedented times.

Therefore, the study seeks to answer two main questions: i) How do we promote and conduct online CPD on action research during the movement control order (MCO), and ii) How do educators exhibit their professional development as a result of participating in the online CPD?

\section{LITERATURE REVIEWS}

Continuous Professional Development (CPD) can be structured and organised in a number of different ways, and for a number of different reasons. While most CPD experiences might be considered as means of introducing or enhancing knowledge, skills and attitudes, it cannot be assumed that this is uncontested (Kennedy, 2005). Research indicates that effective CPD is sustained, content-based, contextually-situated, and educator-centred (Bissonnette \& Caprino, 2014). Successful CPD should be school-based and continuous because an absence of sustained context, a lack of guidance, and follow-up sessions often result in a lack of implementation (Blau, et al., 2011). Blau, et al. (2011) also emphasises that research on educators CPD indicates the importance of intensive sustained, school-based programmes if educators are to adopt new practices and redefine existing ones in significant ways. The intensive, sustained, school-based CPD is possible with action research. Action research has found favour with educators and teacher educators since its introduction into the educational arena through the works of Carr and Kemmis, Elliott and Stenhouse (see Adelman 1993).

In education, action research can be defined as deep inquiry into one's own practice: a systematic, intentional, and reflective study by educators of their own classroom practice for understanding and improvement of that practice (Carr \& Kemmis, 1986; Cochran-Smith \& Lytle, 2009). The process of action research has proven to be a powerful tool for educator CPD (Zeichner, 2003). Research shows that training educators to function as action researchers in their own practices has benefits for the educator themselves, their students, and the entire school community (Cochran-Smith \& Lytle, 1990; Llewellyn \& Van Zee, 2010; Mertler, 2009). Action research is sustained, content-based, contextually-situated, and educator-centred: all qualities of effective professional development. Educators become engaged in the professional development process when it involves action research as it allows for explicit discussion of the events, challenges, and successes in their own classroom. Professional development becomes more meaningful when it involves action research because it allows for the integration of a question directly related to the educator's content (Cochran-Smith \& Lytle, 1990).

Online platform is an option for CPD with lots of potential (Cornelius \& Macdonald, 2008). Geographic boundaries are not a limiting factor with online CPD because online platform is Internet based. Online CPD opens up opportunities for collaboration among educators across states and districts regardless of distance (Gaumer et al., 2012). Online platform allows options for selection of delivering tools. 
One example is that the online CPD can be synchronous or asynchronous. Examples of synchronous include chat rooms, video and conference technology. Examples of asynchronous learning include e-mail, threaded forums, and news groups. Studies designed to examine the key components of effective online CPD identify three primary types of interaction. These three types of interactions are educator to teacher educator, teacher to teacher, and teacher to content (Nandi et al., 2012). Properly designed online CPD should be interactive, collaborative, interest-driven and differentiated, ongoing, consisting of the proper resources, and properly implemented (Elliott, 2017).

\section{METHODS}

The study utilised action research as a model of Continuous Professional Development (CPD) to impart understandings about action research processes to the educators. This model has been acknowledged as being successful in allowing educators to ask critical questions of their practice (Kennedy, 2005). Similarly, Burbank and Kauchack (2003) argue that this model provides an alternative to the passive role imposed on educators in traditional models of professional development. We also attest that this model has significant capacity for transformative practice and professional autonomy in order to support educators to critically reflect upon their pedagogical practices during the COVID-19 pandemic. Following an action research model for continuous professional development, we applied the four phases of the action research spiral in the study (as shown in the Figure 1 below), namely the development of the online CPD, implementation of the online CPD, data collection processes from the online CPD and reflection about the online CPD. The action research spiral offers us an opportunity to review the processes of delivering online CPD at a higher level each time and thus to progress towards better outcomes.

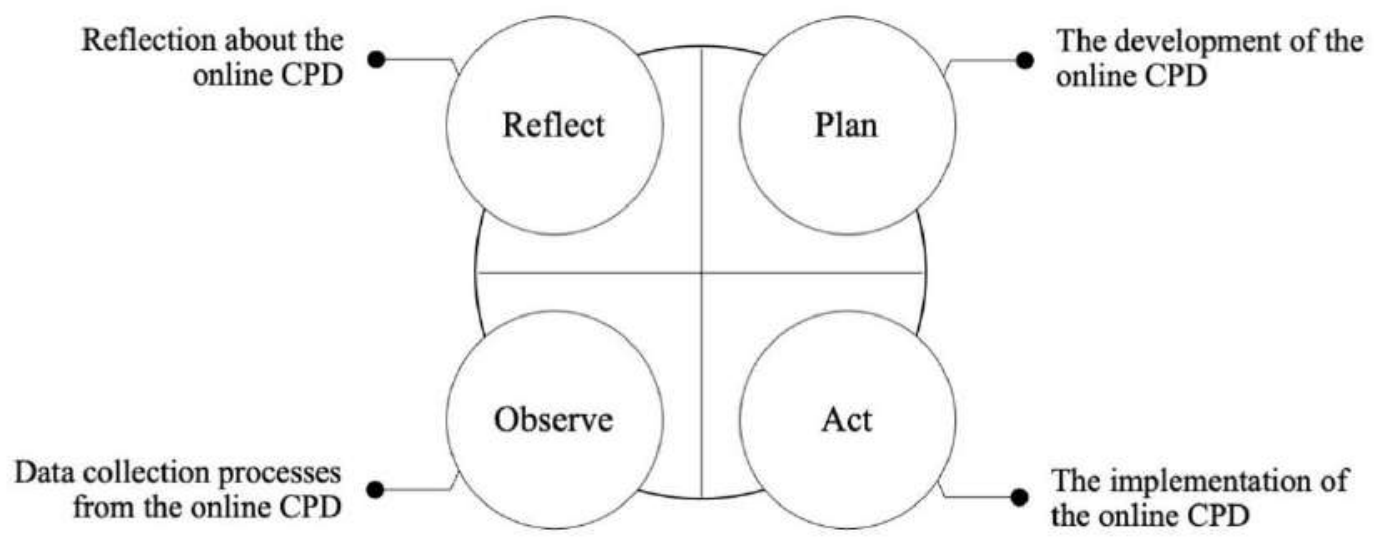

Figure 1. The four phases of the action research spiral employed in the study.

We employed mixed methods action research when we collect, analyse, and integrate both quantitative and qualitative data within the study to generate practical knowledges (Ivankova \& Wingo, 2018). 
Mixed methods and action research share a number of conceptual, philosophical, and procedural characteristics, which make a meaningful integration of these two research approaches justifiable and advantageous (Ivankova, 2015). We have collected quantitative and qualitative data from the needs assessment in the beginning of the study to determine the appropriate contents and approaches to be adopted in the online CPD. In the final phase of the study, we conducted a quantitative and qualitative evaluation survey about the online CPD, to gather information from the participating educators and evaluate the educators' understanding of action research. The quantitative data collected in the study was analysed using a simple descriptive statistics (May, 2017) in allowing us to describe, organize, and summarize data in a meaningful way. We also did not intend to make presumptive conclusions about the participating educators. The qualitative data collected in the study was analysed using a thematic approach (Mills et al., 2010) in allowing us to identify themes of patterns of contextual meaning.

In this paper we present the study using a narrative approach to describe action research processes on: How do we promote and conduct online CPD on action research during the COVID-19 pandemic? We chose narrative style writing as this approach is very important for developing and writing up action research experiences by paying due attention to the main issues in the process of narrative knowing (making) and narrative telling (communicating) (Taledano \& Anderson, 2020). McNiff (2007) makes explicit the links she sees between narrative approach and action research. Narrative approach and action research are linked as research that enables practitioner researchers to tell their stories of how they have taken action to improve their situations by improving their learning: they explain how reflecting on their action can lead to new learning, which can inform future learning and action (McNiff, 2007). Similarly, Whitehead (1989) emphasises practitioner researchers' stories comprise their description and explanations of practice and, through these stories, these living educational theories of practice, they are able to show how they hold themselves accountable for what they are doing and why they are doing it. Therefore, we applied first person narration in this paper is to reflect the use of narrative approach in the study.

\section{DISCUSSIONS}

\section{How do we promote and conduct online CPD on action research during the movement control order (MCO)?}

Our efforts to promote online Continuous Professional Development (CPD) began with a presentation of our idea to the Director of the Institute of Teacher Education, Raja Melewar Campus. He supported the idea, and the online CPD for the study was registered officially as part of the Online CPD Programme of the Institute. Thus, educators who participated in the online CPD will receive an official Sistem Pengurusan Latihan KPM (SPLKPM) merit from the Ministry of Education (MOE). Soon after the approval, we began to advertise the online CPD. It was promoted through an informative digital poster that was created to attract the attention of educators, primarily primary and secondary school teachers. 
The digital was based on the AIDA Model, a promotional theory in marketing developed by an American advertising and sales pioneer, St Elmo Lewis in 1898, which emphasises attention, interest, desire and action. We adapted the concept of infomercials in marketing (Lee \& Hoffman, 2015) as an innovative educational tool to promote the online CPD to the educators in a convincing way. This was achieved through the creation of an informative digital poster and short videos, and the choice of social media platforms, notably Facebook and Instagram. Numerous empirical studies coincide in indicating that social media can be a useful communication platform and serve as open and rich digital spaces for professionals to exchange information, opinions and ideas (Bruguera, 2019).

We engaged a professional graphic designer to create a digital poster which contains the name and theme of the online CPD, as well as relevant images and information. We clearly included our positions and qualifications as action research instructors in an attempt to create a good image. The digital poster also contained information about who we are and our role as action research instructors for the online CPD. The underlying principles sought to ensure that our target educators felt supported and connected. We wanted to put forward action research as a support system for educators who were struggling with distance learning challenges. We clearly indicated that the number of participants was limited to encourage them to register. The digital poster, together with short videos promoting the online CPD, were widely shared via social media platforms, which are Facebook and Instagram, and mobile applications, namely WhatsApp and Telegram. Our choice to promote the online CPD was in line with the Social Media for Learning (SM4L) Framework of Middleton and Bengkingham (2015) (as shown in the Table 1 below). One of the advantages of using social media to promote online CPD during the movement control order (MCO) was to support open access, through geographically extended, democratic, inclusive, user-controlled, free, open and accessible content. Social media also accommodate common interests among learners and enable the discussion of diverse topics.

Table 1. Social Media for Learning (SM4L) Framework Characteristics that generate learning opportunities

1. Support access to new ideas

2. Expand learners' communication and facilitate interaction and sharing

3. Enable connections through social, professional and learning networks

4. Support and expand 'traditional' learning or professional development

5. Promote self-direction, self-regulation, self-expression, enjoyment and confidence of students 
6. Support open access (geographically extended, democratic, inclusive and usercontrolled; free, open and accessible content)

7. Support and validate learning through communities of practice

8. Accommodate common interests among learners and enable discussion of topics

9. Facilitate asking for help or just-in-time information

We promoted the online CPD to educators nationwide through social media platforms, regardless of their background, level of education or teaching experiences. This was part of our effort to promote social justice among educators in Malaysia. Brydon-Miller and Damons (2019) emphasised that educational action research should not only provide professional development, but also should address larger structural issues. Thus, social justice is embedded within the study process, which began within the community itself, and focused on ensuring that all educators could express their interest by registering for the online CPD. As a result, 215 educators registered via Google Forms after two weeks of promoting the online CPD (as shown in the Figure 2 below). At the beginning of the study, we primarily targeted in-service primary and secondary school teachers as we sought to deliver online CPD to these target educators. Interestingly, educators from higher education intuitions also registered for the online CPD, including teacher educators $(n=17)$, pre-university lecturers $(n=7)$, and university lecturers $(n=3)$. The majority of the educators registered for the online CPD were school teachers, including primary school teachers $(n=117)$ and secondary school teachers $(n=65)$. The remaining educators were education officers $(n=4)$ and school administrators $(n=1)$.

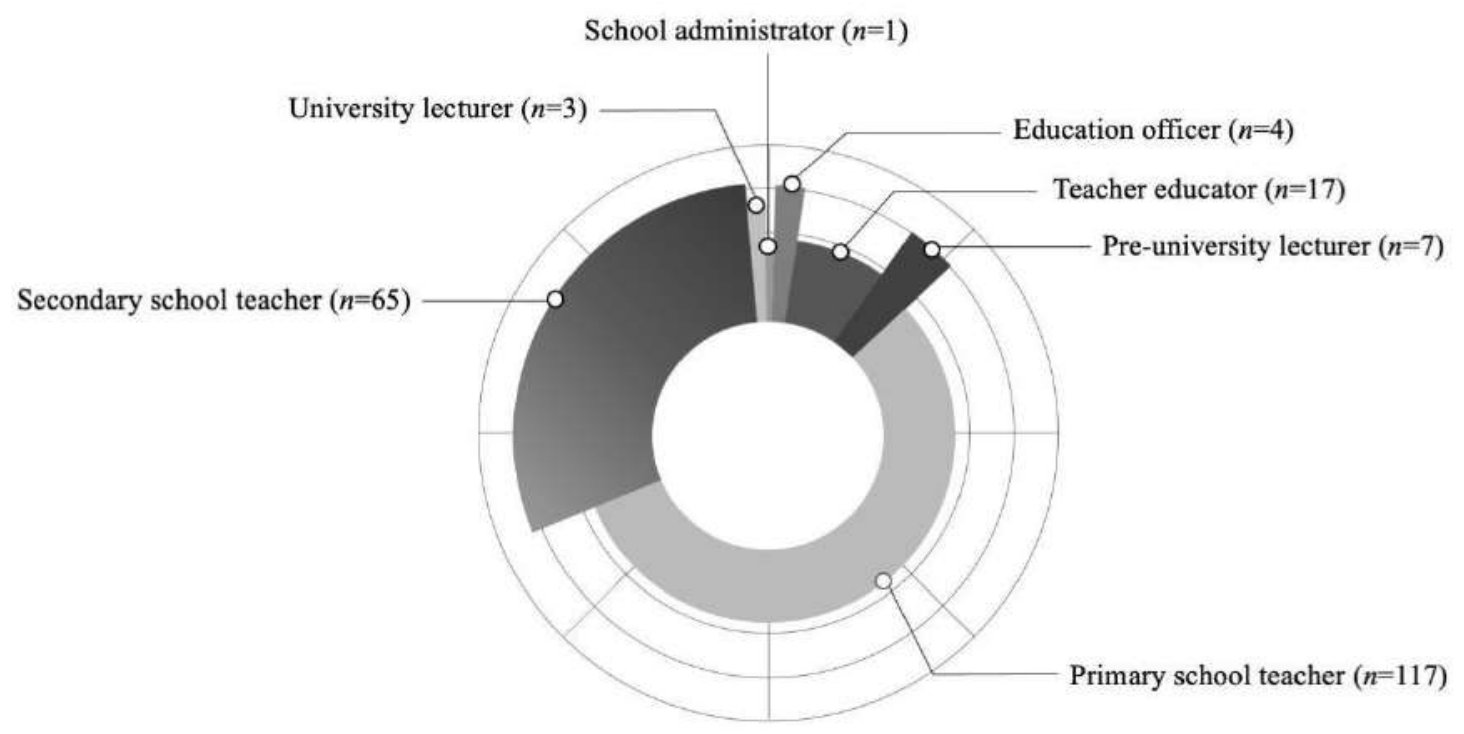

Figure 2. Registered educators in the online CPD. 
In the development of the online CPD, we conducted quantitative and qualitative needs assessments to gather information from the registered educators and to determine the appropriate contents and approaches to be adopted in the online CPD (Rothery \& Tutty, 2001). We used a quantitative needs assessment to gather data that are translated into numerical form and are described using simple statistics. We also utilised a qualitative needs assessment to ask questions that tend to be more open-ended and to allow the educators to describe in detail the complexities of the needs at hand. The 48-item needs assessment was distributed to the registered educators in the online CPD using Google Forms and 33 of them were completed. A quantitative analysis of this needs assessment summarised in the Table 2 below. The study found that only 12 educators (36.4\%) have received training on action research and have been involved in action research projects. The remaining 21 educators (63.6\%) have not received any training on action research and have not been involved in any action research projects. An analysis of the qualitative needs assessments indicated that most educators expressed an interest in and hope for the online CPD to be used to enhance knowledge. Four kinds of knowledge summaries can be drawn from the needs assessments, which are also necessary for teaching practices (Johnson, 2019), namely pedagogical knowledge, pedagogical content knowledge, content knowledge, and knowledge of learners and learning.

Table 2. Summarised quantitative responses from the needs assessment.

\begin{tabular}{|c|c|c|c|c|c|c|}
\hline & \multirow[b]{2}{*}{$\begin{array}{l}\text { 'How much do you agree with this } \\
\text { statement?' items }\end{array}$} & \multicolumn{5}{|c|}{ Responses ( $n=$ number of educators) } \\
\hline & & 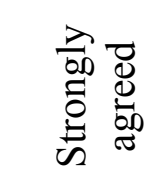 & 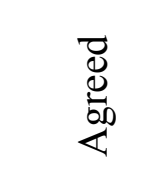 & $\begin{array}{l}\bar{\pi} \\
\stackrel{\Xi}{0} \\
\text { Z }\end{array}$ & 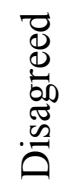 & 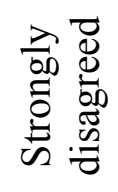 \\
\hline 1. & $\begin{array}{l}\text { 'Action research practice improves the } \\
\text { overall educational quality at } \\
\text { institutional level' }\end{array}$ & $\begin{array}{c}23 \\
(69.7 \%)\end{array}$ & $\begin{array}{c}9 \\
(27.3 \%)\end{array}$ & $\begin{array}{c}1 \\
(3 \%)\end{array}$ & & \\
\hline 2. & $\begin{array}{l}\text { 'Action research helps educators to } \\
\text { analyse their own teaching practice' }\end{array}$ & $\begin{array}{c}27 \\
(81.8 \%)\end{array}$ & $\begin{array}{c}5 \\
(15.2 \%)\end{array}$ & $\begin{array}{c}1 \\
(3 \%)\end{array}$ & & \\
\hline 3. & $\begin{array}{l}\text { 'Action research on teaching improves } \\
\text { student's learning' }\end{array}$ & $\begin{array}{c}27 \\
(81.8 \%)\end{array}$ & $\begin{array}{c}4 \\
(12.1 \%)\end{array}$ & $\begin{array}{c}1 \\
(3 \%)\end{array}$ & & $\begin{array}{c}1 \\
(3 \%)\end{array}$ \\
\hline 4. & $\begin{array}{l}\text { 'Successful implementation of action } \\
\text { research depends upon a educator's } \\
\text { individual desire to learn and implement } \\
\text { new skills during teaching' }\end{array}$ & $\begin{array}{c}27 \\
(81.8 \%)\end{array}$ & $\begin{array}{c}5 \\
(15.2 \%)\end{array}$ & $\begin{array}{c}1 \\
(3 \%)\end{array}$ & & \\
\hline 5. & $\begin{array}{l}\text { 'Support from senior management is a } \\
\text { crucial factor for implementing action } \\
\text { research practice' }\end{array}$ & $\begin{array}{c}21 \\
(63.6 \%)\end{array}$ & $\begin{array}{c}9 \\
(27.3 \%)\end{array}$ & $\begin{array}{c}3 \\
(9.1 \%)\end{array}$ & & \\
\hline
\end{tabular}

From the needs assessments, we developed the contents and approaches for the online CPD. It was divided into three workshops and a webinar. 
The workshops are: i) An introduction to action research, ii) Methodological approaches for action research, iii) Writing an action research report. The first workshop focused on the main ideas, aims and goals of the study. We offered explanations as to why educators need to carry out action research during these unprecedented times, and described action research processes, in particular how to begin their action enquiry by identifying a research focus. The second workshop highlighted how to formulate research questions, develop an intervention in action research, collect data and analyse data systematically. The third workshop outlined some of the key features of an action research report, and explained how the content and form of action research reports are different from traditional research reports. Meanwhile, the webinar on a living educational theory approach to action research and pedagogical practices was conducted with Professor Dr Jack Whitehead from the University of Cumbria, United Kingdom. This webinar aimed to share his original ideas on living educational theory, as the conceptual framework that enables individual educators to locate their enquiries within this research approach.

The online CPD utilised video conferencing tools, notably Google Meet, to deliver all the three workshops synchronously, and Zoom to conduct a webinar. We chose Google Meet to deliver the three workshops as all educators had been provided with a G Suite Education account from the Ministry of Education (MOE) during the movement control order (MCO) to conduct distance teaching and learning during. Within the G Suite Education, we also created and used Google Classroom as a collaborative space for the instructors and the registered educators, and for the registered educators amongst themselves. This asynchronous learning space was also employed to post announcements, organise and manage tasks given during each workshop, and to share resources with participating educators. The combination of online learning approaches, synchronous and asynchronous learning, provided us with two ways to engage the educators. However, we found that the synchronous virtual environment worked more effectively in workshop discussions, as compared to the asynchronous learning environment. On the other hand, we chose Zoom to organise a webinar because of its relative ease of use, cost-effectiveness, data management features, and security options (Archibald, et al, 2019). The webinar was streamed live to YouTube to gather a greater number of educators, so that they could also benefit from the online CPD apart from the registered educators.

\section{How do educators exhibit their professional development as a result of participating in the online CPD?}

In the final phase of the study, we conducted an evaluation survey about the online CPD, to gather information from the participating educators, by adapting the protocol of the CPD Evaluation Framework of Goodall et al. (2005). The participating educators in the study were invited to complete a 27 -item questionnaire via Google Forms. As a result, the study recorded 28 responses. The questionnaire gathered a mixture of quantitative and qualitative data. There were also a few close-ended questions, followed by largely open-ended questions, to afford greater freedom to the participating educators in the ways they choose to answer. A quantitative analysis of this evaluation survey summarised in the Table 3 below. 
Most interestingly, 20 educators (71.4\%) strongly agreed and 7 educators (25\%) agreed with the statement number four: 'The online CPD stimulated my interest in action research'. This was evident that action research interest among educators was being translated into practice, as 17 educators $(60.7 \%)$ stated that they were conducting action research projects during the pandemic COVID-19.

Some of the action research projects described by the educators are: i) The integration of web applications and technology devices to teach modern geometry in synchronous learning, ii) Parental involvement in mathematics learning at home during the movement control order (MCO), and iii) Creating a motivated learning environment in asynchronous learning.

Table 3. Summarised quantitative responses from an evaluation survey of the study. Responses ( $n=$ number of educators)

'How much do you agree with this statement?' items

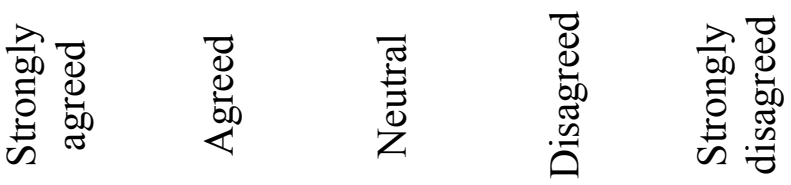

\begin{tabular}{|c|c|c|c|c|}
\hline 1. & $\begin{array}{l}\text { 'The online CPD was useful to my } \\
\text { professionalism' }\end{array}$ & $\begin{array}{c}20 \\
(71.4 \%)\end{array}$ & $\begin{array}{c}8 \\
(28.6 \%)\end{array}$ & \\
\hline 2. & $\begin{array}{l}\text { 'Knowledge and information gained } \\
\text { from participation at the online CPD met } \\
\text { my expectations' }\end{array}$ & $\begin{array}{c}22 \\
(78.6 \%)\end{array}$ & $\begin{array}{c}4 \\
(14.3 \%)\end{array}$ & $\begin{array}{c}2 \\
(7.1 \%)\end{array}$ \\
\hline 3. & $\begin{array}{l}\text { 'Knowledge and information gained } \\
\text { from participation at the online CPD } \\
\text { will be useful/applicable in my work' }\end{array}$ & $\begin{array}{c}21 \\
(75 \%)\end{array}$ & $\begin{array}{c}6 \\
(21.4 \%)\end{array}$ & $\begin{array}{c}1 \\
(3.6 \%)\end{array}$ \\
\hline 4. & $\begin{array}{l}\text { 'The online CPD stimulated my interest } \\
\text { in action research' }\end{array}$ & $\begin{array}{c}20 \\
(71.4 \%)\end{array}$ & $\begin{array}{c}7 \\
(25 \%)\end{array}$ & $\begin{array}{c}1 \\
(3.6 \%)\end{array}$ \\
\hline 5. & $\begin{array}{l}\text { 'I look forward to participating in the } \\
\text { similar CPD in future' }\end{array}$ & $\begin{array}{c}20 \\
(71.4 \%)\end{array}$ & $\begin{array}{c}7 \\
(25 \%)\end{array}$ & $\begin{array}{c}1 \\
(3.6 \%)\end{array}$ \\
\hline 6. & $\begin{array}{l}\text { 'My perception towards action research } \\
\text { has changed from participation at the } \\
\text { online CPD' }\end{array}$ & $\begin{array}{c}18 \\
(64.3 \%)\end{array}$ & $\begin{array}{c}7 \\
(25 \%)\end{array}$ & $\begin{array}{c}3 \\
(10.7 \%)\end{array}$ \\
\hline 7. & $\begin{array}{l}\text { 'From the online CPD, I found that the } \\
\text { methodological approach of action } \\
\text { research is different to conventional } \\
\text { research' }\end{array}$ & $\begin{array}{c}17 \\
(60.7 \%)\end{array}$ & $\begin{array}{c}8 \\
(28.6 \%)\end{array}$ & $\begin{array}{c}3 \\
(10.7 \%)\end{array}$ \\
\hline 8. & $\begin{array}{l}\text { 'In the context of education, action } \\
\text { research is aimed at improving } \\
\text { teaching/pedagogical practices' }\end{array}$ & $\begin{array}{c}20 \\
(71.4 \%)\end{array}$ & $\begin{array}{c}7 \\
(25 \%)\end{array}$ & $\begin{array}{c}1 \\
(3.6 \%)\end{array}$ \\
\hline
\end{tabular}

From the qualitative data, we evaluated the educators' understanding of action research through open-ended questions such as: i) 'What is your current understanding of action research?' and ii) 
In what ways the methodological approach of action research differs from traditional research? Similar to the results of Feldman et al.'s (2018) work, which sought to improve action research practice, most of the educators stated that the importance of engaging in action research during these unprecedented times was to critically evaluate and improve their practice. The educators also stated that critical reflection is an important process in action research to find a solution to a particular issue related to teaching practice. In action research, critical reflection is taken to a deeper level. The question of 'how' to critically reflect is an important consideration that could be prefaced by the question 'can it be learnt?' (Coghlan \& Brydon-Miller, 2014). Furthermore, most educators in our study stated that they realised that when conducting a piece of action research, the subject of the research itself is themselves, rather than the students, as in conventional classroom-based research. The educators also agreed that they are now able to see that action research is a legitimate form of research.

From the qualitative analysis of this evaluation survey, we attested that the participating educators exhibited their professional development and deepened their knowledge related to the four areas: pedagogical knowledge, pedagogical content knowledge, content knowledge, and knowledge of learners and learning. Firstly, pedagogical knowledge. Most of the participating educators stated that the online CPD has made them think critically on the knowledge of general teaching strategies to impart information, teach skills, or enhance learning. This includes teaching strategies in the middle of pandemic COVID-19 such as distance teaching and learning, blended learning and hybrid learning. Secondly, pedagogical content knowledge. The educators stated that they have identified teaching strategies to teach specific content or skills. For example, a special educational needs teacher described that sight words is the best teaching strategy to teach children with down syndrome to read. Thirdly, content knowledge. This is a body of knowledge related to the subject matter that is to be taught. Most of the participating educators stated that the online CPD has guided them in deciding what is taught and in what order. Finally, knowledge of learners and learning. The educators stated the importance of the learning process, learning theories, and human development and it relation to the social, emotional, intellectual, moral, and personal development.

\section{CONCLUSION}

Since the beginning of the movement control order (MCO), the number of students in Malaysia who have not been able to attend or have missed school or university because of COVID-19 has been soaring. As teacher educators, we invested in our study in the form of providing an online CPD on action research to educators to keep education going through distance teaching and learning. The study indicated that social media platforms, which are Facebook and Instagram, and mobile applications, namely WhatsApp and Telegram, act as strong tools to promote and create awareness of the online CPD during these unprecedented times. We attested that synchronous (via Google Meet and Zoom) and asynchronous (via Google Classroom) learning approaches are the best possible platform to deliver online CPD to educators in Malaysia. 
The main purpose of these social media platforms, mobile applications and video conferencing tools is to support open access to educators, in the form of geographically extended, democratic, inclusive, user-controlled, free, open and accessible content, during the COVID-19 pandemic.

Most importantly, the study supported the idea of action research as a systematic approach to initiate professional development among educators to reflect and improve their pedagogical practices during these times. In this study, we encouraged educators to engage in action research, as this systematic inquiry can offer a powerful form of professional development for educators (Johnson \& Button, 2000). In this regard, our effort to provide online CPD on action research has: i) helped educators to develop new knowledge directly related to their teaching practices, ii) promoted reflective teaching and thinking, and iii) expanded educators' pedagogical repertoire. Furthermore, the participating educators exhibited their professional development and deepened their knowledge related to the four areas: pedagogical knowledge, pedagogical content knowledge, content knowledge, and knowledge of learners and learning. Based on these findings, we attested that action research acts as a systematic approach to initiate professional development among educators. It is therefore suggested that action research as a model of CPD should be nurtured among educators to solve educational issues, notably distance teaching and learning.

\section{ACKNOWLEDGEMENT}

The online CPD conducted in the study is officially registered as part of the Online Continuous Professional Development (CPD) of the Institute Teacher Education, Raja Melewar Campus. The study has been reviewed and approved by the Educational Planning and Research Division (EPRD), Ministry of Education, Malaysia (Ref: KPM.600-3/2/3eras(7416)). We thank to Susan Noffke Action Research Foundation, United Kingdom for providing a small award to aid local translation and dissemination of this study.

\section{REFERENCES}

Adelman, C. (1993). Kurt Lewin and the origins of action research. Educational Action Research, 1(1), 7-24. https://doi.org/10.1080/0965079930010102

Archibald, M. M., Ambagtsheer, R. C., Casey, M. G., \& Lawless, M. (2019). Using zoom videoconferencing for qualitative data collection: Perceptions and experiences of researchers and participants. International Journal of Qualitative Methods, 18, 1-8. https://doi.org/10.1177\%2F1609406919874596

Bissonnette, J. D., \& Caprino, K. (2014). A call to action research: Action research as an effective professional development model. Mid-Atlantic Education Review, 2(1), 12-22.

Blau, S.D., Cabe, R.H., \& Whitney, A. (2011). Evaluating IIMPaC: Teacher and student outcomes through a professional development program in the teaching of writing (Executive summary). Santa Barbara, California: South Coast Writing Project at the University of California, Santa Barbara.

Bruguera, C., Guitert, M., \& Romeu, T. (2019). Social media and professional development: A systematic review. Research in Learning Technology, 27, 1-18. https://doi.org/10.25304/rlt.v27.2286

Brydon-Miller, M., \& Damons, B. (2019). Action research for social justice advocacy. In C. A. Mertler (Ed.), The Wiley Handbook of Action Research in Education (pp. 371-92). John Wiley \& Sons, Inc. https://10.1002/9781119399490

Burbank, M. D., \& Kauchak, D. (2003). An alternative model for professional development: Investigations into effective collaboration. Teaching and Teacher Education, 19(5), 499-514. 
Carr, W., \& Kemmis, S. (1986). Becoming critical: Education, knowledge and action research. New York, NY: Routledge Falmer.

Cochran-Smith, M., \& Lytle, S. L. (1990). Research on teaching and teacher-research: The issues that divide. Educational Researcher, 19(2), 2-10.

Cochran-Smith, M., \& Lytle, S.L. (Eds.) (2009). Inquiry as stance: Practitioner research for the next generation. New York, NY: Teachers College Press.

Coghlan, D. \& Brydon-Miller, M. (2014). Critical reflection. In D. Coghlan \& M. Brydon-Miller (Eds.), The SAGE Encyclopedia of Action Research (pp. 225-230). SAGE Publications Ltd. https://dx.doi.org/10.4135/9781446294406

Cornelius, S., \& Macdonald, J. (2008). Online informal professional development for distance tutors: Experiences from The Open University in Scotland. Open Learning, 23(1), 43-55. https://doi.org/10.1080/02680510701815319

Elliott, J. C. (2017). The evolution from traditional to online professional development: A review. Journal of Digital Learning in Teacher Education, 33(3), 114-125, https://doi.org/10.1080/21532974.2017.1305304

Fals-Borda, O. (1987). The application of participatory action-research in Latin America. International Sociology, 2(4), 329-347. https://doi.org/10.1177\%2F026858098700200401

Feldman, A., Altrichter, H., Posch, P., \& Somekh, B. (2018). Teachers investigate their work: An introduction to action research across the professions (3rd ed.). Routledge. https://doi.org/10.4324/9781315398822

Gaumer Erickson, A. S., Noonan, P. M., \& McCall, Z. (2012). Effectiveness of online professional development for rural special educators. Rural Special Education Quarterly, 31(1), 22-31.

Goodall, J., Day, C., Lindsay, G., Muijs, D., \& Harris, A. (2005). Evaluating the impact of continuing professional development (CPD) - Research report RR659. Department for Education and Skills. https:/researchportal.bath.ac.uk/en/publications/evaluating-the-impact-of-continuing-professionaldevelopment

Ivankova, N. (2015). Mixed methods applications in action research: From methods to community action. SAGE Publications, Inc.

Ivankova, N., \& Wingo, N. (2018). Applying mixed methods in action research: Methodological potentials and advantages. American Behavioral Scientist, 62(7) 978-997. https://doi.org/10.1177\%2F0002764218772673

Johnson, M. J., \& Button, K. (2000). Connecting graduate education in language arts with teaching contexts: The power of action research. English Education, 32(2), 107-126. https://www.jstor.org/stable/40173012

Kemmis, S., McTaggart, R., \& Nixon, R. (2014). The Action Research Planner: Doing Critical Participatory Action Research. Springer Science \& Business Media. https://doi.org/10.1007/978-981-4560-67-2

Kennedy, A. (2005). Models of continuing professional development: A framework for analysis. Journal of Inservice Education, 31(2), 235-250. https://doi.org/10.1080/13674580500200277

Lee, S. H., \& Hoffman, K. D. (2015). Learning the ShamWow: Creating infomercials to teach the AIDA model. Marketing Education Review, 25(1), 9-14. https://doi.org/10.1080/10528008.2015.999586

Llewellyn, D., \& van Zee, E. (2010). Action research: expanding the role of classroom teachers to inquirers and researchers. Science Scope, 34(1), 10.

May, A. (2017). Simple Descriptive Statistics. In M. Allen (Ed.), The sage encyclopedia of communication research methods (pp. 1602-1606). SAGE Publications, Inc. https://dx.doi.org/10.4135/9781483381411.n566

McNiff, J. (2007). My story is my living educational theory. In D. J. Clandinin (Ed.), Handbook of narrative inquiry: Mapping a methodology (pp. 308-29). SAGE Publications, Inc. https://dx.doi.org/10.4135/9781452226552.n12

Middleton, A., \& Beckingham, S. (2015). Social media for learning: a framework to inspire innovation. In M. Andrew (Ed.), Smart Learning: Teaching and Learning with Smartphones and Tablets in Post-compulsory Education (pp. 46-56). MELSIG, Sheffield Hallam University.

Mills, A. J., Durepos, G., \& Wiebe, E. (2012). Thematic analysis. In A. J. Mills, G. Durepos \& E. Wiebe (Eds.), Encyclopedia of case study research (pp. 926-927). https://dx.doi.org/10.4135/9781412957397

MOE (2019, January 31). Statistics on the number of schools, teachers and students. Ministry of Education Malaysia. https://www.moe.gov.my/en/statistik-menu/statistik-bilangan-sekolah-murid-guru

MOE (2020, March 27). Surat Siaran Kementerian Pendidikan Malaysia Bilangan 3 Tahun 2020 - Garis Panduan Pelaksanaan Pengajaran dan Pembelajaran (PdP) Semasa Perintah Kawalan Pergerakan Disebabkan Penularan Jangkitan Covid-19. Ministry of Education Malaysia. https://www.moe.gov.my/pekeliling/3361 surat-siaran-kpm-bilangan-3-tahun-2020-garis-panduan-pelaksanaan-pengajaran-dan-pembelajaran-pdpsemasa-pkp-disebabkan-penularan-jangkitan-covid-19/file 
Nandi, D., Hamilton, M., \& Harland, J. (2012). Evaluating the quality of interaction in asynchronous discussion forums in fully online courses. Distance Education, 33(1), 5-30. https://doi.org/10.1080/01587919.2012.667957

PMO (2020, March 16). Speech by YAB Tan Sri Muhyiddin Hj Mohd Yassin Prime Minister of Malaysia 16 March 2020. Prime Minister's Office of Malaysia. https://www.pmo.gov.my/wpcontent/uploads/2020/03/PMs-Speech-ENG-Translation-FINAL.pdf

Rothery, M. A., \& Tutty, L. M. (2001). Needs assessments. In B. A. Thyer (Ed.), The Handbook of Social Work Research Methods (pp. 160-175). SAGE Publications, Inc. https://dx.doi.org/10.4135/9781412986182.n9

Toledano, N., \& Anderson, A. R. (2017). Theoretical reflections on narrative in action research. Action Research, 18(3), 302-318. https://doi.org/10.1177/1476750317748439

Townsend, A. (2014). Collaborative action research. In D. Coghlan \& M. Brydon-Miller (Ed.), The SAGE Encyclopedia of Action Research (pp. 117-119). SAGE Publications, Inc. https://10.4135/9781446294406.n57

Whitehead, J. (1989). Creating a living educational theory from questions of the kind, 'How do I improve my practice?'. Cambridge Journal of Education, 19(1), 137-53. https://doi.org/10.1080/0305764890190106

Zeichner, K. (2003). Teacher research as professional development for P-12 educators in the USA. Educational Action Research, 2(2), 301-326. 